\title{
PENGUATAN PEMAHAMAN MATERI LINTAS BUDAYA BAGI GURU MGMP BAHASA MANDARIN
}

\author{
Lukluk UI Muyassaroh'1), Octi Rjeky Mardasari'1), Aiga Ventivani1'), Karina Fefi Laksana Sakti1), \\ Nurruddin Aniq Zahran Risqi Atho'ullah"1), Trikora Mahardhika')
}

1)S1 Pendidikan Bahasa Mandarin, Sastra, Universitas Negeri Malang, Malang, Jawa Timur, Indonesia

Corresponding author : Lukluk UI Muyassaroh

E-mail : lukluk.ul.fs@um.ac.id

Diterima 23 Oktober 2021, Direvisi 25 Desember 2021, Disetujui 25 Desember 2021

\begin{abstract}
ABSTRAK
Saat ini, dengan meningkatnya hubungan politik, budaya, ekonomi dan pendidikan antara Indonesia dengan China, membuat hubungan antara kedua negara secara bertahap semakin hangat dan erat. Kedudukan bahasa Mandarin di Indonesia juga sangat penting. Hal tersebut terbukti dengan semakin meningkatnya kesadaran masyarakat akan pentingnya bahasa Mandarin dan diimbangi dengan semakin banyaknya instansi atau lembaga pendidikan yang membuka pembelajaran bahasa Mandarin. Dampak dari peningkatan investasi adalah dibangunnya banyak perusahaan dan membantu Indonesia dalam penyerapan tenaga kerja. Kelancaran kegiatan usaha tentunya perusahaan tersebut banyak membutuhkan tenaga kerja yang mampu berkomunikasi lancar bahasa Mandarin. Dari observasi dan wawancara yang dilakukan oleh peneliti terhadap MGMP bahasa Mandarin di kota Malang mendapatkan hasil data berupa guru memerlukan penguatan pemahaman terhadap wawasan bahasa Mandarin pada aspek materi lintas budaya. Metode pelaksanaan yang digunakan yaitu metode pembimbingan, diskusi dan ceramah. Data yang diambil selain dari data observasi selama dilaksanakan kegiatan juga mengambil data hasil kegiatan yang didapat berdasarkan angket yang disebar. Hasil dan tanggapan positif dapatkan dari hasil observasi maupun angket dan terlihat sekali antusias para guru dalam mengikuti kegiatan yang dilaksanakan dan juga pemahaman materi lintas budaya. Harapan peneliti melalui pelatihan yang singkat ini terjadinya jalinan komunikasi yang lebih baik guna membantu mengatasi kendala yang dihadapi dalam melakukan pembelajaran Mandarin.
\end{abstract}

Kata kunci: pemahaman; mandarin; lintas budaya; MGMP.

\begin{abstract}
Currently, with the increasing political, cultural, economic and educational relations between Indonesia and China, the relations between the two countries are gradually getting warmer and closer. The position of Chinese in Indonesia is also very important. This is evidenced by the increasing public awareness of the importance of Chinese and balanced by the increasing number of institutions or educational institutions that open Chinese language learning. The smooth running of business activities, of course, the company requires a lot of workers who are able to communicate fluently in Chinese. From observations and interviews conducted by researchrers on The Chinese MGMP in the city of Malang obtained data results in the form of teachers requiring strengthening understanding of Chinese language insights on cross-cultural aspects of material. The implementation method used is the method of mentoring, discussion and lecture. The data taken apart from observation data during the activities carried out also took data from the results of activities obtained based on the questionnaires distributed. Positive results and responses were obtained from the results of observations and questionnaires and it was seen that the teachers were very enthusiastic in participating in the activities carried out and also understanding cross-cultural material. The researchers hope that through this short training, there will be a better communication network to help overcome the obstacles faced in learning Chinese.
\end{abstract}

Keywords: understanding; chinese; cross-cultural; MGMP.

\section{PENDAHULUAN}

Saat ini, dengan meningkatnya hubungan politik, ekonomi dan pendidikan antara Indonesia dengan China, membuat hubungan antara kedua negara secara bertahap semakin hangat dan erat. Hubungan tersebut menimbulkan dampak positif, salah satunya meningkatkan peluang kerjasama di bidang ekonomi maupun pendidikan. Hal tersebut sejalan dengan teori yang dikemukakan oleh (Setiawan, 2012) China merupakan salah satu kekuatan utama 
ekonomi dunia dan bersama dengan dua negara Asia Timur lainnya yaitu Jepang dan Korea Selatan. Ketiga negara tersebut telah menjadi mitra dagang terpenting Indonesia dan juga ASEAN dari tahun ke tahun. Selain itu menurut (Jacques, 2011) satu-satunya pemain ekonomi global yang paling berpengaruh di Asia Timur adalah China dan nantinya pengaruh China terhadap dunia akan semakin besar dan sama pengaruhnya seperti Amerika Serikat dalam adab akhir ini. Pengaruh besar kekuatan China di Indonesia terbukti dengan adanya jalinan kerjasama yang telah dibangun antara China dengan Indonesia. China telah memberikan sumbangsih besar dalam berbagai bidang salah satunya pada dunia pendidikan Indonesia. Contoh adanya sumbangsih dari kerjasama tersebut adalah negara China memberikan beasiswa bagi mahasiswa Indonesia dalam bentuk kegiatan pertukaran pelajar, membangun fasilitas pendidikan dan mengirim sejumlah besar guru sukarelawan China ke Indonesia.

Kedudukan bahasa Mandarin di Indonesia juga sangat penting, pentingnya bahasa Mandarin dan pengaruh besar dari kekuasaan yang dimiliki negeri adidaya China sangat berpengaruh pada dunia pendidikan. Hal tersebut terbukti dengan semakin meningkatnya kesadaran masyarakat akan pentingnya bahasa Mandarin dan diimbangi dengan semakin banyaknya instansi atau lembaga pendidikan yang membuka pembelajaran bahasa Mandarin. Pentingnya bahasa Mandarin juga diungkapkan oleh (Lane, 2019) menyebutkan bahwa jumlah penutur asli 1,3 miliar, kira-kira 917 juta berbicara bahasa Mandarin hal tersebut membuktikan bahwa bahasa Mandarin adalah bahasa yang paling banyak digunakan di dunia. Teori lain dikemukakan oleh (Yulius, 2010) menurut Yulius bahasa Mandarin diakui sebagai bahasa Internasional, hal tersebut juga semakin dirasa penting oleh masyarakat. Hangatnya kerjasama Indonesia dengan China maka investasi negara China di Indonesia juga semakin meningkat. Dampak dari peningkatan investasi adalah dibangunnya banyak perusahaan dan membantu Indonesia dalam penyerapan tenaga kerja. Kelancaran kegiatan usaha tentunya perusahaan tersebut banyak membutuhkan tenaga kerja yang mampu berkomunikasi lancar bahasa Mandarin oleh karena itu bahasa Mandarin di Indonesia mempunyai kedudukan yang sangat penting dalam menyerap tenaga kerja Indonesia dan membantu mengatasi kesulitan masyarakat dalam mendapatkan pekerjaan.(Busri et al., 2016) Pemahaman lintas budaya mampu memunculkan sensitivitas budaya, yang ditandai dengan perubahan dari yang tadinya "melihat realitas hanya dari sudut pandang budayanya sendiri" menuju pada "menyadari akan adanya banyak sudut pandang lain di dunia ini". Melihat kondisi tersebut peneliti melakukan observasi dan wawancara terhadap subjek yaitu guru bahasa Mandarin di kota Malang yang tergabung dalam MGMP bahasa Mandarin sebagai acuan mengetahui kondisi pembelajaran bahasa Mandarin dan kendala yang dihadapi oleh pengajar bahasa Mandarin di kota Malang.

Dari observasi dan wawancara yang dilakukan oleh peneliti mendapatkan hasil data berupa guru memerlukan penguatan pemahaman terhadap wawasan bahasa Mandarin pada aspek materi lintas budaya. Berkomunikasi lintas bangsa juga berkomunikasi lintas budaya yang mana komunikasi semacam ini dapat dapat menjadi penghambat tercapainya komunikasi yang efektif(Mulyana, 2010). Dengan kata lain bahasa dan budaya merupakan dua hal yang tak terpisahkan dari sebuah komunikasi lintas budaya (Sukmayadi, 2018). Adanya kendala dilatar belakangi oleh beberapa hal pengalaman guru (pernah tidaknya ke China) dan sulitnya mencari sumber informasi mengenai materi lintas budaya China di Indonesia. Menurut (Trihardini et al., 2019) penguasaan materi budaya dapat dilakukan melalui 2 jenis kegiatan berkomunikasi: (1) komunikasi lintas budaya verbal, komunikasi lintas budaya non verbal.

Pentingnya guru menguasai materi lintas budaya adalah untuk dapat memberikan variasi pemahaman materi dan memaksimalkan penyampaian materi kepada siswa sehingga siswa tidak jenuh dan lebih termotivasi belajar bahasa Mandarin. Materi lintas budaya diputuskan menjadi kendala yang perlu diselesaikan dalam penelitian ini karena sedikitnya sumber referensi materi lintas budaya dan sedikitnya peneliti terdahulu yang memberikan solusi terhadap masalah ini. Dampak adanya kendala keterbatasan pemahaman tersebut mengakibatkan penyampaian informasi kepada peserta didik dalam memahami materi bahasa Mandarin kurang maksimal. Materi lintas budaya merupakan hal dasar yang harus dan penting diketahui karena bahasa dan budaya memiliki kaitan yang sangat erat. Menurut paparan oleh Koentjaraningrat (Chaer, 2010) bahwa kondisi dan kebudayaan memiliki pengaruh terhadap bahasa yang digunakan dalam berkomunikasi sehari-hari. dan menurut (Trihardini et al., 2019) hubungan erat antara bahasa dan 
budaya juga yang meyakini bahwa bahasa sebagai unsure pembentuk kebudayaan.

Berdasarkan temuan peneliti, kemampuan guru dalam pemahaman materi lintas budaya tidak memadai maka perlu dilakukan langkah yang signifikansi dengan tujuan para guru nantinya akan mempunyai wawasan dan kapabilitas untuk memberikan pembelajaran, oleh karena itu penelitian berjudul "Pelatihan Materi Pemahaman Lintas Budaya bagi MGMP Bahasa Mandarin SeMalang Raya" ini penting dilakukan agar dapat mengatasi dan membantu anggota MGMP bahasa Mandarin se-Malang Raya dalam memahami materi lintas budaya. Adapun langkah langkah dalam mengatasi permasalahan tersebut adalah (1) pengalaman guru (pernah tidaknya ke China) hal tersebut dapat diatasi dengan cara melakukan pelatihan yang direncanakan dilaksanakan dengan materi yang memiliki topik menarik dan dengan mendatangkan narasumber native speakers untuk dapat memastikan kondisi yang sesungguhnya dengan materi yang disampaikan sesuai dan benar adanya; (2) dari segi sulitnya mencari sumber belajar mengenai materi lintas budaya China peneliti akan membuat sebuah buku pegangan sebagai pedoman guru dalam memahami materi lintas budaya; (3) dari segi sulitnya mengakses data sumber mengenai materi lintas budaya peneliti juga menambahkan materi mengenai tips dan triks dalam mencari sumber materi lintas budaya pada website China. Kegiatan pengabdian kepada masyarakat ini memiliki tujuan yaitu semoga guru sebagai pendidik menjadi lebih percaya diri mampu menggali wawasan untuk meningkatkan mutu pendidikan.

Pelatihan ini diharapkan dapat memberikan manfaat (1) terbentuknya forum pembelajaran guru yang memberikan fasilitasi kegiatan peningkatan kompetensi guru Mengembangkan kepekaan budaya peserta pelatihan; (2) Peserta pelatihan memahami di mana orang Indonesia-China memiliki latar belakang budaya yang berbeda; (3) Peserta pelatihan memahami perberdaan komunikasi antara budaya Indonesia- China; (5) Peserta pelatihan memahami perbedaan pola pikir orang Indonesia- China; (6) Peserta pelatihan memahami perbedaan adat istiadat orang Indonesia- China ; (7) Peserta pelatihan mampu mengantisipasi makna yang akan diterima tidak sesuai (kesalahan pemaknaan) oleh penerima ; (8) Peserta pelatihan dapat berkomunikasi dengan menyesuaikan diri dengan perbedaan yang ada.

\section{METODE}

Pada bagian ini peneliti melaksanakan pelatihan dengan judul "Penguatan Pemahaman Materi Lintas Budaya bagi MGMP Bahasa Mandarin se-Malang Raya" . Metode pelaksanaan yang digunakan yaitu metode pembimbingan, diskusi dan ceramah. Data yang diambil selain dari data observasi selama dilaksanakan kegiatan juga mengambil data hasil kegiatan yang didapat berdasarkan angket yang disebar. Langkah dan tahapan kegiatan pelatihan adalah sebagai berikut:

Pelaksanaan pelatihan yang dilakukan dibagi menjadi beberapa tahapan adalah sebagai berikut:

(a) Mengkomunikasikan dan menginformasikan kepada guru bahasa Mandarin yang tergabung dalam MGMP bahasa Mandarin se-Malang Raya yang menjadi mitra. Pada tahap ini, tim peneliti menghubungi ketua MGMP bahasa Mandarin se-Malang Raya untuk mendiskusikan kegiatan yang akan dilaksanakan.

(b)Tahap selanjutnya yaitu sosialisasi mengenai rencana pelaksanaan kegiatan Penguatan Pemahaman Materi Lintas Budaya bagi MGMP bahasa Mandarin. Setelah sosialisasi dilaksanakan, tim peneliti menyebarkan angket untuk menjaring informasi ketersediaan kesediaan guru bahasa Mandarin mengikuti kegiatan.

(c)Tahap pelaksanaan. Pada bagian ini terdapat tahap Pelaksanaan kegiatan yang terdiri dari beberapa tahapan 1) Pengarahan pada tahap awal; 2) Memaparkan keuntungan dan kerugian (tidak memahami materi lintas budaya); 3) Memaparkan makna dari materi lintas budaya; 4) Sesi diskusi dan tanya jawab.

(d) Tahapan evaluasi kegiatan. Pada tahap ini dilakukan evaluasi terhadap seluruh aspek pelaksanaan kegiatan termasuk output yang dihasilkan. Untuk mendapatkan informasi dan mengetahui hasilnya peneliti menggunakan tabel observasi dan media angket terbuka dalam angket tersebut terdapat kolom kolom pertanyaan dan wajib dijawab oleh peserta. Observer pada penelitian ini berasal dari tim panitia pelaksana.

\section{HASIL DAN PEMBAHASAN}

Pada bagian ini dipaparkan mengenai hasil dari pelaksanaan kegiatan. Kegiatan pengabdian dilaksanakan secara daring menggunakan media platform Zoom pada tanggal 5 Agustus 2021 dan diikuti 14 orang guru. Kegiatan ini mendatangkan narasumber seorang native speakers untuk dapat memastikan kondisi yang sesungguhnya dengan materi yang disampaikan sesuai dan benar adanya. Terdapat tahap pelaksanaan 
kegiatan yang terdiri dari beberapa tahapan (1) Pengarahan pada tahap awal, para guru diberikan pengarahan tentang pentingnya pemahaman materi lintas budaya dalam pengajaran bahasa Mandarin; Memaparkan keuntungan (memahami materi lintas budaya) dan kerugian (tidak memahami materi lintas budaya) guru diberikan penjelasan secara detail mengenai keuntungan (memahami materi lintas budaya) dan kerugian (tidak memahami materi lintas budaya); (3) Memaparkan makna dari materi lintas budaya pada tahap ini pemateri menjelaskan mengenai makna dari materi lintas budaya kepada guru guru bahasa Mandarin. Pada setiap sesi guru-guru diwajibkan memperhatikan demonstrasi penggunaan untuk dapat memahami materi yang telah dijelaskan; (4) Sesi diskusi dan tanya jawab. Pada sesi dan tanya jawab mekanismenya yang pertama yaitu pemateri mengajukan pertanyaan mengenai opini para guru terhadap topik pelatihan dan yang kedua para guru dipersilahkan untuk mengajukan pertanyaan mengenai materi dan berdiskusi dengan pemateri). Kegiatan ini juga dilengkapi dengan sebuah buku yang telah dirancang sebelumnya untuk membantu para guru mereview materi setelah kegiatan, adapun gambaran bukunya dibawah ini:

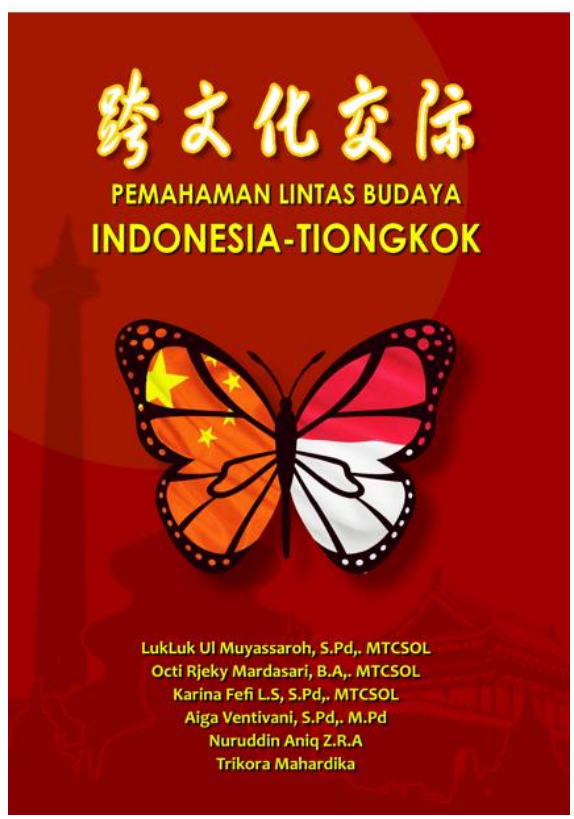

Gambar 1. Cover Depan

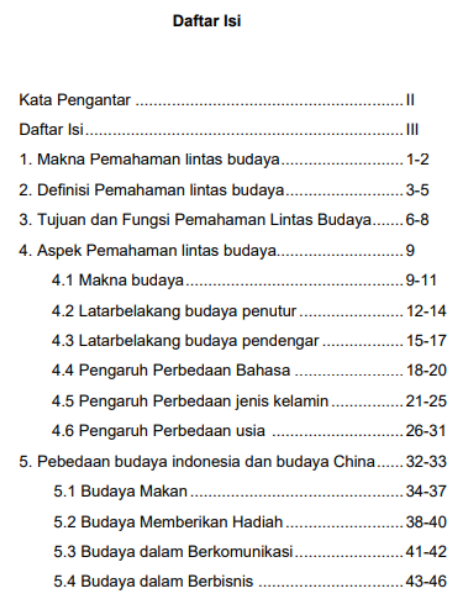

Gambar 2. Daftar Isi

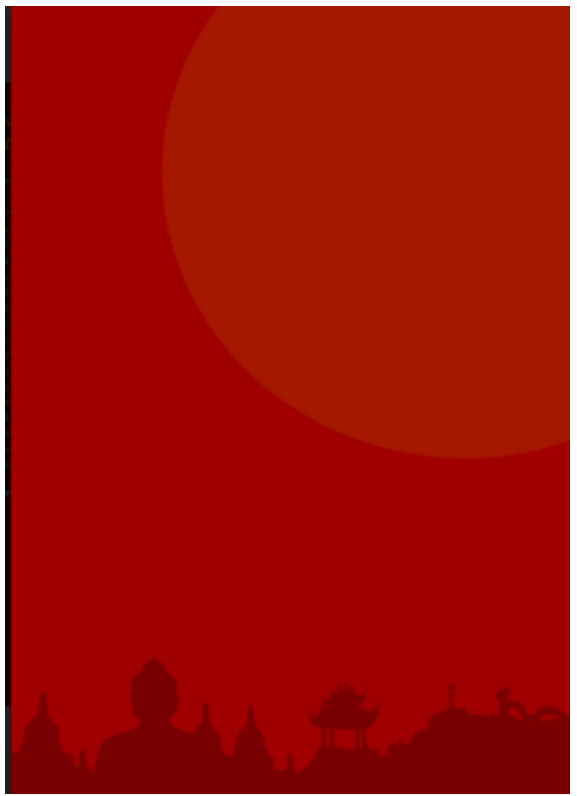

Gambar 3. Cover Belakang

Berdasarkan data yang diperoleh melalui media angket adapun uraian manfaat dan hasil yang didapat oleh Guru MGMP bahasa Mandarin adalah sebagai berikut :

Tabel 1. Respon peserta pelatihan

\begin{tabular}{|c|c|}
\hline Responden & Uraian \\
\hline 1 & $\begin{array}{l}\text { Materinya menambah wawasan } \\
\text { karena memanglah banyak } \\
\text { perbedaan di antara Indonesia } \\
\text { dan Tiongkok. }\end{array}$ \\
\hline 2 & $\begin{array}{l}\text { Sangat bagus untuk menambah } \\
\text { pemahaman tentang lintas } \\
\text { budaya }\end{array}$ \\
\hline 3 & $\begin{array}{lrr}\text { Jadi tau } & \text { tentang } \\
\text { perbedaan/kebiasaan } & \text { orang } \\
\text { Indonesia dan China. } & \\
\end{array}$ \\
\hline
\end{tabular}




\begin{tabular}{|c|c|}
\hline 4 & $\begin{array}{l}\text { Sangat membantu saya atas } \\
\text { pembelajar Pemahaman materi } \\
\text { lintas budaya }\end{array}$ \\
\hline 5 & $\begin{array}{l}\text { Materi yang disampaikan } \\
\text { menambah pengetahuan saya } \\
\text { mengenai budaya-budaya China } \\
\text { yang belum saya ketahui. }\end{array}$ \\
\hline 6 & $\begin{array}{l}\text { Materi sangat bermanfaat. dapat } \\
\text { membantu siswa yang sedang } \\
\text { mempersiapkan untuk program } \\
\text { pertukaran pelajar dan untuk guru } \\
\text { yang mempersiapkan siswanya } \\
\text { untuk program pertukaran pelajar }\end{array}$ \\
\hline 7 & $\begin{array}{l}\text { Sangat bagus, dan sangat } \\
\text { bermanfaat. Karena menambah } \\
\text { pengetahuan } \\
\text { Pemahaman budaya }\end{array}$ \\
\hline 8 & $\begin{array}{l}\text { Isi materi sangat menarik dan } \\
\text { memberi insight lebih mengenai } \\
\text { budaya tiongkok }\end{array}$ \\
\hline 9 & $\begin{array}{l}\text { Sangat bagus dan bermanfaat } \\
\text { juga mempelajari budaya China } \\
\text { dan indonesia }\end{array}$ \\
\hline 10 & $\begin{array}{l}\text { Menambah pengetahuan tentang } \\
\text { perbedaan budaya indonesia dan } \\
\text { tiongkok }\end{array}$ \\
\hline 11 & $\begin{array}{l}\text { Sangat membantu saya dalam } \\
\text { pemahan lintas budaya }\end{array}$ \\
\hline 12 & $\begin{array}{l}\text { Sangat menambah wawasan saya } \\
\text { terhadap perbedaan budaya } \\
\text { kedua negara }\end{array}$ \\
\hline 13 & $\begin{array}{l}\text { Penyampaian materi sangat baik, } \\
\text { saya jadi dapat mempelajari yang } \\
\text { disampaikan oleh pemateri } \\
\text { brrdasarkan materi serta budaya } \\
\text { dan pengalaman. }\end{array}$ \\
\hline 14 & $\begin{array}{l}\text { Sangat menambah wawasan saya } \\
\text { terhadap perbedaan budaya } \\
\text { kedua negara }\end{array}$ \\
\hline
\end{tabular}

Berdasarkan hasil obseravasi yang telah peneliti lakukan selama kegiatan pelatihan yang telah dilaksanakan didapatkanlah informasi (1) Terbentuknya forum pembelajaran guru yang memberikan fasilitasi kegiatan peningkatan kompetensiO guru Mengembangkan kepekaan budaya peserta pelatihan; (2) Peserta pelatihan memahami di mana orang Indonesia- China memiliki latar belakang budaya yang berbeda; (3) Peserta pelatihan memahami perbedaan komunikasi antara budaya Indonesia- China; (5) Peserta pelatihan memahami perberdaan pola pikir orang Indonesia- China; (6) Peserta pelatihan memahami perbedaan adat istiadat orang Indonesia- China; (7) Peserta pelatihan mampu mengantisipasi makna yang akan diterima tidak sesuai (kesalahan pemaknaan) oleh penerima; (8) Peserta pelatihan dapat berkomunikasi dengan menyesuaikan diri dengan perbedaan yang ada; (9) Terjalinnya hubungan komunikasi yang lebih baik antara Prodi pendidikan bahasa Mandarin UM dengan pihak guru MGMP bahasa Mandarin Malang; (8) Informasi mengenai kondisi kendala yang dihadapi guru dalam mengajarkan bahasa Mandarin lebih banyak, sehingga peneliti dapat mempersiapkan materi yang sekiranya akan dilakukan untuk pelatihan selanjutnya.

Tujuan dari memahami materi lintas budaya menurut (Anggraeni \& Rachmijati, 2017) adalah mampu berkomunikasi dengan baik dengan manusia yang berbeda kebudayaan, memperdalam pengalaman atau pengetahuan, membuat peka dengan budaya sendiri, membantu memahami ketika ada kontak antar budaya, dan terlibat dengan budaya lain agar menciptakan hubungan yang langgeng. Oleh karena itu memahami materi lintas budaya bagi pembelajar bahasa adalah penting.

\section{SIMPULAN DAN SARAN}

Berdasarkan uraian di atas dapat disimpulkan bahwa pelatihan penguatan pemahaman materi lintas budaya bahasa Mandarin penting dilakukan. Hasil dan tanggapan positif dapatkan dari hasil observasi maupun angket. Hal tersebut terlihat sekali dari antusias para guru dalam mengikuti kegiatan yang dilaksanakan. Peningkatan pemahaman materi lintas budaya para guru tampak jelas sehingga pada akhir kegiatan para guru juga antusias bertanya dan juga mengharapkan kegiatan seperti ini rutin dilakukan. Harapan peneliti melalui pelatihan yang singkat ini terjadinya jalinan komunikasi yang lebih baik antara Universitas Negeri Malang dengan MGMP bahasa Mandarin seMalang Raya sehingga kedepannya terdapat pelatihan lanjutan pada bidang lainnya. Hal tersebut guna membantu mengatasi kendala yang dihadapi dalam melakukan pembelajaran Mandarin. Saran dari peserta pelatihan adalah alangkah baiknya terdapat subtitle/keterangan mengenai bahasa Indonesia atau english karena ada beberapa peserta yang masih belum banyak mengetahui beberapa hanzi maupun makna nya.

\section{UCAPAN TERIMAKASIH}

Kegiatan dan artikel ini tidak akan dapat terselesaikan dengan baik tanpa bantuan dari berbagai pihak. Untuk itu, peneliti 
mengucapkan terima kasih yang sebesarbesarnya atas segala bantuan dan dukungannya dalam penyelesaian artikel ini kepada (1) Universitas Negeri Malang; (2) Kepala LP2M Universitas Negeri Malang, Prof. Dr. Markus Diantoro, M.Si.; (3) Dekan Fakultas Sastra, Universitas Negeri Malang, Prof. Utami Widiati, M.A., Ph.D.; (4) Kaprodi Pendidikan Bahasa Mandarin, Dr. Dewi Kartika A., M.Pd., dan pihak yang tidak bisa peneliti sebutkan satu per satu yang telah membantu penulisan artikel dan pelaksana kegiatan mulai dari awal sampai akhir.

\section{DAFTAR RUJUKAN}

Anggraeni, A., \& Rachmijati, C. (2017). APLIKASI PEMAHAMAN LINTAS BUDAYA (CROSSCULTURAL UNDERSTANDING) DALAM PEMBELAJARAN SPEAKING UNTUK MENGATASI KECEMASAN BERBICARA (SPEAKING ANXIETY) PADA MAHASISWA SEMESTER 2 PROGRAM STUDI BAHASA INGGRIS STKIP SILIWANGI. Jurnal IImiah P2M STKIP Siliwangi, 4(2), 3239.https://doi.org/10.22460/p2m.v4i2p 32-39.639

Busri, H., Irawati, R. P., \& Nawawi, M. (2016). PEMANFAATAN CROSS CULTURAL UNDERSTANDING (PEMAHAMAN LINTAS BUDAYA) DALAM BAHAN AJAR NUSUS ADABIYYAH (ANALISIS TEKS SASTRA). Jurnal Penelitian Pendidikan, 33(1), 35-58. https://doi.org/10.15294/jpp.v33i1.766 3

Chaer, A. (2010). Sosiolinguistik Perkenalan Awal. Rineka Cipta.

Jacques, M. (2011). When China rules the world (ketika china menguasai dunia): Kebangkitan dunia timur dan akhir dunia barat. PT Gramedia Pustaka Utama.

Lane, J. (2019). The 10 Most Spoken Languages In The World. Babbel Magazine.

https://www.babbel.com/en/magazine/ the-10-most-spoken-languages-inthe-world

Mulyana, D. (2010). Komunikasi Lintas Budaya. Rosda.

Setiawan, S. (2012). ASEAN-CHINA FTA: DAMPAKNYA TERHADAP EKSPOR INDONESIA DAN CINA. Buletin Ilmiah Litbang Perdagangan, 6(2), 129-150. https://doi.org/10.30908/bilp.v6i2.97

Sukmayadi, V. (2018, September 11). Pembelajaran Lintas Budaya Melalui Pendekatan Sosial Kemasyarakatan
Volume 5, Nomor 1, Desember 2021.

p-ISSN : 2614-5251

e-ISSN : 2614-526X

(Studi kasus pada Kelas Mahasiswa Internasional Pembelajar BIPA).

Trihardini, A., Wikarti, A. R., \& Andriani, S. (2019). PEMAHAMAN LINTAS BUDAYA BAGI PENDIDIK BAHASA MANDARIN. Jurnal Cakrawala Mandarin, 2(2), 28-36. https://doi.org/10.36279/apsmi.v2i2.6 4

Yulius, H. (2010). Mudah \& Lancar Belajar Bahasa Mandarin untuk Pemula. TransMedia. 